Borneo Journal of Sciences \& Technology, 3(2): 59-64

DOI: http://doi.org/10.3570/bjost.2021.3.2-10

e-ISSN: 2672-7439

(C) 2018, UCTS Publisher.

\begin{tabular}{lll}
\hline Submitted: $02^{\text {nd }}$ March 2021 & Accepted: $15^{\text {th }}$ July 2021 & Published: $31^{\text {st }}$ July 2021
\end{tabular}

\title{
The Physicochemical Properties of Stingless Bee Honey: A Review
}

\author{
Jacky Tung Jiong Loh, Chen Chung Koh, and *Siew Ling Hii \\ Food Technology Programme, School of Engineering and Technology, \\ University College of Technology Sarawak, 96000 Sibu, Sarawak, Malaysia
}

\begin{abstract}
:
Honey is a saturated sugary solution derived from the nectar of flowers collected by worker bees. The main constituents of honey are water, sugars, proteins, minerals, and organic acids. Malaysia has a wide distribution of stingless bees, especially the Heterotrigona itama species. The composition of stingless bee honey is greatly dependent on its geographical origins and the flora sources. This leads to huge variations in stingless bee honey obtained from different regions. In Malaysia, stingless bee honey is being sold as a health-promoting product, although its composition and therapeutic effects have never been studied in detail. Thus, the need to study the properties of stingless bee honey is apparent. A brief review of the physicochemical properties of stingless bee honey is presented here. The main parameters reviewed are moisture, $\mathrm{pH}$, hydroxymethylfurfural, ash, electrical conductivity, antioxidant activity, total phenolic content, and total flavonoid content.
\end{abstract}

Keywords: Honey, Stingless bee, Physicochemical properties

\section{INTRODUCTION}

Honey is a saturated sugary solution derived from the nectar of flowers collected by worker bees. Honey is mainly composed of water, carbohydrates, proteins, sugars, phenolic acid, flavonoids, enzymes, and organic acids [1]. Honey has been used as a traditional medicine due to its chemical and physical composition. For instance, it has been used for centuries for wound healing as well as curing certain diseases [2]. The most remarkable functions of honey are their antioxidant and antibacterial activities [3].

The most common and popular honeybee species in the world is Apis mellifera, which is a type of western honeybee. The stingless bee is less common compared to A. mellifera. There are about 500 different species of stingless bees discovered in the world. A total of sixty species can be found in Asia [3]. According to Azri et al. [4], the most common stingless bees that exist in Malaysia are the Trigona species and Melipona species. The Melipona species is widely distributed throughout the world where its population could rival that of the $A$. mellifera species. Unlike western honeybees, stingless bees are smaller in size. Stingless bees do not cause harm to humans as their stings have undergone evolutionary decline. Stingless bees produce and store less honey compared to A. mellifera. Moreover, the colour and taste of stingless bee honey are different from those of $A$. mellifera honey [5]. The production of honey by stingless bees is limited and there is a lack of international and institutional standards as well as research knowledge [6]. Today, researchers are interested in studying the various properties of stingless bee honey as it has high functional variability [5]. The physicochemical properties of stingless bee honey are mainly influenced by flora type, climate, and geographical region [7].

Although the characteristics of stingless bee honey are not yet fully studied, it has gained popularity as a health-promoting natural product [8]. The nutrients of stingless bee honey could improve and maintain the metabolism rate, circulatory system, and physiological reactions [9]. Rao et al. [7] stated that stingless bee honey can lower cardiovascular risk.

The main purpose of this paper is to review the physicochemical properties of stingless bee honey. The main physicochemical properties reviewed are moisture content, $\mathrm{pH}$, sugar content, hydroxymethylfurfural content, ash, electrical conductivity, antioxidant activity, total phenolic content, and total flavonoid content.

\section{Malaysian Standard MS 2683: 2017}

Malaysian Standard MS 2683 governs the quality of stingless bee honey in Malaysia [10]. The standard states the minimum quality requirements for some of the

*Corresponding Author: Siew Ling Hii, School of Engineering and Technology, University College of Technology Sarawak

(UCTS), Email: hiisl@ucts.edu.my 
principal parameters, such as moisture, sucrose content, fructose and glucose content, maltose content, of stingless bee honey as depicted in Table 1 .

\section{Moisture}

Moisture content is the quantity of water in honey. According to MS 2683, the moisture content of stingless bee honey should not be more than 35\% [10]. According to Baroni et al. [9], the climatic conditions as well as maturity of honey played a significant role in determining the moisture content of the honey. Vit et al. [11] concluded that the moisture content of stingless bee honey was higher compared to A. mellifera honey. They further suggested that the maximum moisture content of stingless bee honey should be $30 \mathrm{~g} / 100 \mathrm{~g}$ of sample. Research conducted by Chuttong et al. [12] showed that the highest moisture content for twenty eight samples of Thailand stingless bee honey was $47 \mathrm{~g} / 100 \mathrm{~g}$ while the lowest was $25 \mathrm{~g} / 100 \mathrm{~g}$. Suntiparapop et al. [13] also analysed the moisture content of nineteen Thai stingless bee honey of Tetragonula leaviceps species from two different locations, i.e., Chantaburi $(n=13)$ and Trat ( $n$ $=6$ ). The moisture contents were found to be $27.46 \pm$ $0.23 \%$ and $26.50 \pm 0.24 \%$ respectively. The stingless bee honey from Australia possessed an average moisture content of $25.4 \pm 1.0 \%$ [14]. Nascimento et al. [15] reported that the range of moisture content for Brazilian stingless bee honey was from $26.0 \%$ to $35 \%$. Lower moisture content could prolong the shelf life of stingless bee honey. This is due to the inhibition of microbial growth as well as the prevention of the fermentation process.

\section{pH}

$\mathrm{pH}$ is a value that expresses the acidity or alkalinity of a solution. As reported by Vit et al. [6], stingless bee honey has a lower $\mathrm{pH}$ value that leads to greater acidity and sourness compared to A. mellifera honey. This property might affect consumers' preferences of stingless bee honey. The lower $\mathrm{pH}$ value of stingless bee honey is due to the presence of organic acids such as citric acid, acetic acid, gluconic acid, and benzoic acid. As fermentation takes place during storage, the acidity of stingless bee honey become higher. Furthermore, the $\mathrm{pH}$ of the nectar consumed by the bees also affects the acidity of the stingless bee honey produced [15].

The $\mathrm{pH}$ of thirty three stingless bee honey samples from Brazil ranged from 3.33 to 6.56 [16]. Another research by Nascimento et al. [15] showed that the average value of $\mathrm{pH}$ of thirty Brazilian stingless bee samples varied from 2.93 to 4.08 . Besides that, the $\mathrm{pH}$ for stingless bee honey from Thailand reported an average value of $3.6 \pm 0.198$ [12]. The average $\mathrm{pH}$ value for Australian stingless bee honey was slightly higher, i.e., $\mathrm{pH} 3.85 \pm 2.6$ [14]. Study performed by Oddo et al.
[17] on Australian Trigona carbonaria honey also reported similar mean $\mathrm{pH}$ value of $4.0 \pm 0.1$.

The Malaysian $H$. itama stingless bee honey recorded a mean $\mathrm{pH}$ value of $3.26 \pm 0.17$ [18], which complied with MS 2683. A low pH value could prevent the growth of bacteria and thus enhance the honey's antibacterial properties [19].

\section{Sugars}

Honey is a solution of sugary liquid that contains not only the monosaccharides glucose and fructose, it also contains disaccharides such as sucrose and maltose. Majority of the stingless bee honey has low content of oligosaccharides [20]. The sweetness of stingless bee honey is mainly attributed to fructose [2].

Nweze et al. [21] reported that the mean value of reducing sugar for Nigerian stingless bee Melipona species was $75.64 \pm 1.99 \%$ with sucrose content of 5.06 $\pm 0.75 \%$. For the Hypotrigona species, the average reducing sugar was $60.49 \pm 5.21 \%$ and the sucrose content was $1.83 \pm 0.14 \%$. For the twenty eight stingless bee honey from Thailand, the average total sugars content was $51 \pm 21 \mathrm{~g} / 100 \mathrm{~g}$ (fructose, $17 \pm 9.7 \%$; glucose, $14 \pm 8.6 \%$; maltose, $41 \pm 15 \%$; sucrose, $1.2 \pm$ 2.7\%) [12]. According to Chuttong et al. [12], maltose was only detected in three stingless bee species in Thailand - Lepidotrigona terminate, Lepidotrigona flavibasis and Tetragonula laeviceps-pagdeni complex.

Suntiparapop et al. [13] reported that the total reducing sugars for nineteen stingless bee samples ( $T$. laeviceps) from Thailand had a range of $45.5 \%$ to $50.28 \%$. Relatively higher sucrose content was detected from these samples, ranging from $18.9 \%$ to $19.5 \%$. Sugars analysis by Guerrini et al. [5] on Ecuadorian stingless bee honey reported a fructose content of $25.2 \pm$ $3.37 \mathrm{~g} / 100 \mathrm{~g}$, glucose content of $25.5 \pm 3.41 \mathrm{~g} / 100 \mathrm{~g}$ and sucrose content of $3.72 \pm 0.49 \%$. There was, however, no maltose detected in these honey samples. According to Azeredo et al. [22], early harvest of honey from bee hives could be one of the reasons causing high sucrose content in the sample, in which the sucrose has not yet fully been converted into glucose and fructose by the enzyme invertase.

For the stingless bee honey from Sarawak, Malaysia, the reported range were: $12.01 \pm 1.1 \%$ to 19.5 $\pm 1.3 \%$ for fructose, $14.9 \pm 0.7 \%$ to $21.0 \pm 1.7 \%$ for glucose and $33.7 \pm 2.1 \%$ to $45.2 \pm 1.1 \%$ for maltose, with no sucrose detected [3]. Nevertheless, the Malaysian Standard MS 2683 stated that maltose content for Malaysian stingless bee honey should not be more than $9.5 \mathrm{~g} / 100 \mathrm{~g}$.

As reported by Vit et al. [11], the reducing sugar content for Venezuelan stingless bee honey of $48.18 \%$ to $79.94 \%$ were much lower than the Apis mellifera honey with sugar content ranging from $68.4 \%$ to $77.5 \%$. 
Table 1: Malaysian Standard MS 2683: 2017 for raw stingless bee honey

\begin{tabular}{ll}
\hline Characteristics & Requirements \\
\hline Moisture, $\%$ & Not more than 35.0 \\
Sucrose, $\mathrm{g} / 100 \mathrm{~g}$ & Not more than 7.5 \\
Fructose and glucose (sum), $\mathrm{g} / 100 \mathrm{~g}$ & Not more than 85.0 \\
Maltose, $\mathrm{g} / 100 \mathrm{~g}$ & Not more than 9.5 \\
Hydroxymethylfurfural, $\mathrm{mg} / \mathrm{kg}$ & Not more than 30.0 \\
$\mathrm{pH}$ & 2.5 to 3.8 \\
\hline
\end{tabular}

Meanwhile, the sucrose content reported were from $1.09 \%$ to $12.30 \%$. On the other hand, the sugar content of Australian stingless bee (T. carbonaria) honey as reported by Oddo et al. [23] were as follows: fructose content, $24.5 \pm 1.9 \%$; glucose content, $17.5 \pm 2.8 \%$; maltose content, $20.3 \pm 2.9 \%$; and, sucrose content, 1.8 $\pm 0.4 \%$. Biluca et al. [16] reported the total sugar content of thirty three Brazil stingless bee honeys as $48.6 \%$ to $70.5 \%$, with an average value of $62.1 \pm 5.36 \%$. The sucrose content for all the samples were below the quantitation limit of $0.074 \mathrm{mg} / \mathrm{L}$.

Nascimento et al. [15] reported that the average sugar contents of thirty stingless bee honey from Brazil ranged from $66.12 \%$ to $75.21 \%$ with $1.61 \%$ of sucrose content. The authors explained that lower reducing sugars and high moisture content in stingless bee honey were mainly due to rapid fermentation. The fermentation process could be minimised with an appropriate storage of honey samples.

\section{5-Hydroxymethylfurfural (HMF)}

HMF is a type of Maillard reaction product generated due to the reaction of reducing sugars with amino acids at high temperatures [24]. The production of HMF is mainly due to the fructose, acids, high temperature, $\mathrm{pH}$, water content as well as the minerals [25]. The HMF level could be used to determine the honey quality [12]. The lower the HMF contents in the honey, the better the honey's quality is [21]. The concentration of HMF in freshly harvested honey is relatively low, but the concentration increases with longer storage period [26]. Oddo et al. [17] investigated the quality and freshness of honey through HMF determination and honey with HMF content exceeding $10 \mathrm{mg} / \mathrm{kg}$ were excluded from the study. Moo-huchin et al. [27] claimed that HMF could not be detected in fresh honey. In addition, honey produced in tropical regions with higher environmental temperature could cause the production of HMF [12]; 13].

The highest HMF content for the twenty eight stingless bee honey samples from Thailand was 46 $\mathrm{mg} / \mathrm{kg}$ while some of the honey samples did not contain HMF [12], with the mean HMF of $8.7 \pm 12 \mathrm{mg} / \mathrm{kg}$ recorded. Another research involved Thailand stingless bee honey reported the HMF range of $0.25 \mathrm{mg} / \mathrm{kg}$ to 1.89 $\mathrm{mg} / \mathrm{kg}$ [13]. Honey from Australian stingless bee ( $T$. carbonaria) also had an average HMF content of $1.2 \pm$ $0.6 \mathrm{mg} / \mathrm{kg}$ [23]. On the other hand, significant high HMF content (average value of $23.42 \pm 17.79 \mathrm{mg} / \mathrm{kg}$ ) was found in Malaysian stingless bee (H. itama) [18].

\section{Ash}

Ash content is the amount of mineral collected by stingless bee from honey sources [28]. It represents the minerals richness of honey [29]. The average ash content for Thai stingless bee honey was $0.531 \pm 0.632$ $\mathrm{g} / 100 \mathrm{~g}$ [12] and $0.48 \pm 0.06 \mathrm{~g} / 100 \mathrm{~g}$ of ash was detected for the Australian stingless bee (T. carbonaria) honey [23]. Ash content of Brazilian stingless bee honey was reported to be in the range of $0.1 \%$ to $0.3 \%$ [15]. The ash content of Ecuadorian stingless bee (Meliponinae) honey was $0.28 \pm 0.04 \mathrm{~g} / 100 \mathrm{~g}[5]$.

\section{Electrical Conductivity}

Electrical conductivity represents the honeys' mineral content [15]. The electrical conductivity of honey depends on the content of ash and acid. The higher the acid and ashes in honey, the higher the electrical conductivity [30]. There is a relationship between electrical conductivity and ash, however, different parameters were used. For example, electrical conductivity measures the inorganic and ionisable organic compounds while ash only measures inorganic residues after carbonization process of the honey [31].

The electrical conductivity of Ecuadorian stingless

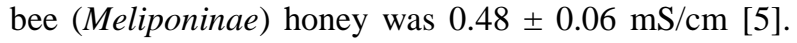
Almost similar range of electrical conductivity ( 0.53 to $0.71 \mathrm{mS} / \mathrm{cm}$ ) was detected for Thai stingless bee honey [13]. The average electrical conductivity reported by Chuttong et al. [12] was slightly higher with an average value of $1.1 \pm 0.78 \mathrm{mS} / \mathrm{cm}$. For one of the Brazilian stingless bee honey, the average value of electrical conductivity was from 514.78 to $728.34 \mu \mathrm{S} / \mathrm{cm}$ [15]. However, significant low level of electrical conductivity ( 0.150 to $1.34 \mathrm{mS} / \mathrm{cm}$ ) was detected for another reported Brazilian stingless bee honey [16]. Australian stingless bee ( $T$. carbonaria) species recorded electrical conductivity with a range of $1.33 \mathrm{mS} / \mathrm{cm}$ to $169 \mathrm{mS} / \mathrm{cm}$ [23]. 


\section{Antioxidant Activity}

Antioxidant activity is the capability of honey to decrease the oxidative reactions in human body that could affect our health [32]. Excessive generation of free radicals results in oxidative stress [33] and a variety of chronic diseases such as cancer, aging, and heart diseases [34]. Wang et al. [35] claimed that antioxidant activity of honey will not be affected by high temperature. In contrast, the elevated temperature could help to improve the antioxidant activity [36].

The antioxidant activity of stingless bee honey can be determined by three major methods namely DPPH (2,2-diphenyl-1-picryl-hydrazyl-hydrate) assay, ABTS (2,2'-azino-bis(3-ethylbenzthiazoline-6-sulphonic acid) assay and FRAP (Ferric Reducing Antioxidant Power) assay. As stated by Otto et al. [23], it was not recommended to measure the antioxidant activity by using a single antioxidant test only. Two or more antioxidant tests should be used to compare the results.

The DPPH radical scavenging effect from thirty three Brazilian stingless bee honeys were within the range from $1.41 \mathrm{mg}$ equivalent ascorbic acid (EAA)/100 $\mathrm{g}$ to $18.5 \mathrm{mg}$ EAA/100 $\mathrm{g}$. The wide variation of results could be due to the different geographical origins of honey samples [16]. The DPPH radical scavenging effect of Brazilian stingless bee honey analysed by Silva et al. [37] were ranging from $10.6 \mathrm{mg}$ EAA/100 $\mathrm{g}$ to $12.9 \mathrm{mg}$ EAA/100 g. For stingless bee honey from Sarawak, the DPPH assay values were ranging from $17.0 \pm 7.5$ to 47.5 $\pm 3.2 \%$ [12].

Oddo et al. [23] analysed the antioxidant activity of Australian stingless bee using both DPPH and ABTS assay methods. The mean ABTS assay value reported for stingless bee (T. carbonaria) honey was $233.96 \pm 50.95$ $\mu \mathrm{M}$ Trolox equivalents while the mean DPPH assay value was $48.03 \pm 12.58 \%$ ascorbic acid equivalent. By using the FRAP assay, a minimum value of $61.1 \mu \mathrm{mol}$ Fe II/100 $\mathrm{g}$ and a maximum value of $624 \mu \mathrm{mol} \mathrm{Fe} \mathrm{II/100}$ $\mathrm{g}$ for the stingless bee honey were reported by Biluca $e t$ al. [16].

By using ABTS cation radical-scavenging tests, the $\mathrm{EC}_{50}$ value for seven stingless bee honeys from Brazil were varied from $210 \pm 0.25$ to $337 \pm 3.17 \mathrm{mg} / \mathrm{mL}$ [37] There was a high correlation between total phenolic content and antioxidant activity [38, 39]. Saric et al. [40] also stated that the total phenolic content and total flavonoid content will affect the antioxidant activity in honey. The antioxidant activity of stingless bee honey is greatly dependent on the geographical region as well as the species of stingless bee [41].

\section{Total Phenolic Content (TPC)}

As reported by Tuksitha et al. [3], the phenolic content for the three Sarawakian stingless bee honey samples ranged from $44.72 \pm 6.50$ to $99.04 \pm 5.14 \mathrm{mg} / \mathrm{mL}$. From their results, the stingless bee honey produced by $H$. itama has the highest phenolic content. According to Kek et al. [42], the total phenolic content present in stingless bee honey (Trigona species) was 33\% higher than that of Apis mellifera honey.

Silva et al. [37] investigated the total phenolic content of Brazilian stingless bee honey and the values obtained varied from 1.30 to $66.0 \mathrm{mg} \mathrm{GAE} / 100 \mathrm{~g}$. Biluca et al. [16] reported the range of 10.3 to $98 \mathrm{mg} \mathrm{GAE} / 100 \mathrm{~g}$ for the total phenolic compounds found in stingless bee honey (Meliponinae). The total phenolic content of $T$. carbonaria stingless bee honey from Australia had an average value of $55.74 \pm 6.11 \mathrm{mg}$ EGA/100 g [23]. The wide variation of the value could be due to different geographical area.

Ranneh et al. [43] analysed the total phenolic content of Malaysian stingless bees (Trigona species) honey harvested from Kedah and Johor Bahru region. The stingless bee honey from Kedah had an average total phenolic content of $228.09 \pm 7.9 \mathrm{mg} \mathrm{GAE} / \mathrm{kg}$ and 235.28 $\pm 0.6 \mathrm{mg} \mathrm{GAE} / \mathrm{kg}$ for stingless bee honey from Johor Bahru. The authors also compared stingless bee honey with Tualang honey, and the result showed that stingless bee honey contains greater amount of total phenolic content.

\section{Total Flavonoid Content (TFC)}

Flavonoids are a type of phenolic compounds with low molecular weight. Flavonoids also play an important role in the antioxidant activity of honeys [11]. The flavonoid content for three Sarawakian stingless bee honey samples varied from $12.41 \pm 0.62$ to $17.67 \pm 0.75 \mathrm{mg} / \mathrm{mL}$ [3]. The highest flavonoid content was detected in the $G$. thoracica species. Malaysian stingless bee honey from Kedah had a total flavonoid content of $97.88 \pm 10.1 \mathrm{mg}$ $\mathrm{CE} / \mathrm{kg}$ while stingless bee honey from Johor Bahru had a total flavonoid content of $101.5 \pm 11.4 \mathrm{mg} \mathrm{CE} / \mathrm{kg}$ [43]. The flavonoid content of Australian (T. carbonaria) stingless bee honey had an average value of $10.02 \pm 1.59$ $\mathrm{mg}$ Quercetin Equivalents (EQ)/100g, which was higher than Czech floral honey $(6.59 \mathrm{mg} \mathrm{EQ} / 100 \mathrm{~g})$ and honeydew honey (7.25 mg EQ/100g) [23].

\section{CONCLUSION}

Stingless bees are distinctive because they produce a rare kind of honey that has gained attention due to its particular characteristics and exotic flavour. However, studies conducted on stingless bee honey are limited compared to those of A. mellifera honey. Therefore, the value of research on Malaysian stingless bee honey is remarkably high. This review paper shows that the physicochemical properties of stingless bee honey are very much affected by the flora sources as well as the geographical regions in which the samples are collected. 


\section{REFERENCES}

[1] Moniruzzaman, M., Chua, Y.A., Pasupuleti, V. R., Mohammad, N. I. H., Siti A.B.M.A., Siti, A.S. and Siew, H. G. 2014. Identification of phenolic acids and flavonoids in monofloral honey from Bangladesh by high performance liquid chromatography: determination of antioxidant capacity. BioMed Research International, 11 pages, Article ID 737490.

[2] Bogdanov, S., Martin, P. and Lullman, C. 1997. Harmonised methods of the European Honey Commission. Apidologie, $1-59$.

[3] Tuksitha, L., Chen, Y. L. S., Chen, Y. L., Wong, K. Y. and Peng, C. C. 2018. Antioxidant and antibacterial capacity of stingless bee honey from Borneo (Sarawak). Journal of Asia-Pacific Entomology, 21, 563 - 570 .

[4] Azri, M. A. J., Razak, A.K. and Hazrina, H. 2017. Stingless bee honey, the natural wound healer: a review. Skin Pharmacology and Physiology, 30, 66 75.

[5] Guerrini, A., Bruni, R., Maietti, S., Poli, F., Rossi, D., Paganetto, G., Muzzoli, M., Scalvenzi, L. and Sacchetti, G. 2009. Ecuadorian stingless bee (Meliponinae) honey: A chemical and functional profile of an ancient health product. Food Chemistry, 114, 1413-1420.

[6] Vit, P., Medina, M. and Enríquez, E. (2004). Quality standards for medicinal uses of Meliponinae honey in Guatemala, México and Venezuela. Bee World, 85(1), 2-5.

[7] Rao, P. V., Krishnan, K. T., Salleh, N. and Siew, H. G. 2016. Biological and therapeutic effects of honey produced by honey bees and stingless bees: a comparative review. Brazilian Journal of Pharmacognosy, 26, 657-664.

[8] Staniškienè, B., Matusevičius, P. and Budreckienè, R. 2006. Honey as an indicator of environmental pollution? Environmental Research, Engineering \& Management, 2(36), 53 - 58.

[9] Baroni, M.V., Arrua, C., Nores, M.L., Faye, P., Diaz, M.P., Chiabrando, G.A. and Wunderlin, D.A. 2009. Composition of honey from Córdoba (Argentina): assessment of north/south provenance by chemometrics. Food Chemistry, 114, 727 733.

[10] Malaysian Standard MS 2683. 2017. Kelulut (Stingless bee) honey - Specification. Department of Standards Malaysia, 33 pages.

[11] Vit, P., Bogdanov, S. and Kilchenman, V. 1994. Composition of Venezuelan honeys from stingless bees and Apis mellifera L. Apidologie, $25,278-288$.

[12] Chuttong, B., Chanbang, Y., Sringarm, K. and Burgett, M. 2015. Physicochemical profiles of stingless bee (Apidae: Meliponini) honey from
South East Asia (Thailand). Food Chemistry, $192,149-155$.

[13] Suntiparapop, K., Prapaipong, P. and Chantawannakul, P. 2012. Chemical and biological properties of honey from Thai stingless bee (Tetragonula leaviceps). Journal of Apicultural Research, 51(1), $45-52$.

[14] Boorn, K.L., Khor, Y.Y., Sweetman, E., Tan, F., Heard, T.A. and Hammer, K.A. 2010. Antimicrobial activity of honey from the stingless bee Trigona carbonara determined by agar diffusion, agar dilution, broth microdilution and time-kill methodology. Journal of Applied Microbiology, 108, 1534 - 1543.

[15] Nascimento, A., Marchini, L., Carvalho, C., Araújo, D., Olinda, R. and Silveira, T. 2015. Physical-chemical parameters of stingless bee honey. American Chemical Science Journal, 7(3), $139-149$.

[16] Biluca, F.C., Gois, J.S., Schulz, M., Braghini, F., Gonzaga, L. V., Maltez, H. F., Rodrigues, E., Vitali, L., Micke, G. A., Borges, D. L. G., Casto, A. C. O. and Fett, R. 2017. Phenolic compounds, antioxidant capacity and bioaccessibility of minerals of stingless bee honey (Meliponinae). Journal of Food Composition and Analysis, 63, $89-97$.

[17] Oddo, L.P., Piazza, M. G. and Pulcini, P. 1999. Invertase activity in honey. Apidologie, 30, 57 65.

[18] Chin, N. L. and Kek, S. P. 2018. Chemical and genetic markers for identification of honey origin from its bee speciation. International Journal of Food Engineering, 4(4), $304-307$.

[19] Malika, N.n Mohamed, F. and Chakib, E. D. 2005. Microbiological and physico-chemical properties of Moroccan honey. International Journal of Agriculture \& Biology, 7(5), 773-776.

[20] Doner, L. W. (1977). The sugars of honey - A review. Journal of the Science of Food and Agriculture, 28, $443-455$.

[21] Nweze, J. A., Okafor, J. I., Newze, E. I. and Nweze J. E. 2017. Evaluation of physicochemical and antioxidant properties of two stingless bee honeys: a comparison with Apis mellifera honey from Nsukka, Nigeria. BMC Research Notes, 10, 566.

[22] Azeredo, L. C., Azeredo, M. A. A., de Souza, S. R. and Dutra, V. M. L. 2002. Protein contents and physicochemical properties in honey samples of Apis mellifera of different floral origins. Food Chemistry, 80, $249-254$.

[23] Oddo, L. P., Heard, T. A., Rodríguez-Malaver, A., Pérez, R. A., Fernández-Muiño, M., Sancha, M. T., Sesta, G., Lusco, L. and Vit, P. 2008. Composition and antioxidant activity of Trigona carbonaria honey 
from Australia. Journal of Medicinal Food, 11 (4), $789-794$.

[24] Durling, L. J. K., Busk, L. \& Hellman, B. E. 2009. Evaluation of the DNA damaging effect of the heatinduced food toxicant 5- hydroxymethylfurfural (HMF) in various cell lines with different activities of sulfotransferases. Food and Chemical Toxicology. $47,880-884$

[25] White Junior, J. W. (1979). Methods for determining carbohydrates, hydroxymethylfurfural, and proline in honey: Collaborative study. Journal of the Association of the Official Analytical Chemistry, 62(3), $\quad 515 \quad-\quad 526$. https://doi.org/10.1093/jaoac/62.3.515

[26] Mohamed, A. S., Abdah, M. A., Ramasamy, K., Hasan, M. H., Hamimi, I. A. and Zalkapli, E. 2018. Physicochemical analysis and sugar profiling of Acacia honey. Malaysian Journal of Microscopy, 14, $157-164$.

[27] Moo-Huchun, V. M., González-Aguilar, G. A., LiraMaas, J. D., Pérez-Pacheco, E., Estrada-León, R., Moo-Huchin, M. I. and Sauri-Duch, E. 2015. Physicochemical properties of Melipona beecheii honey of the Yucatan Peninsula. Journal of Food Research, 4(5), 25 - 32.

[28] Finola, M. S., Lasagno, M. C. and Marioli, J. M. 2007. Microbiological and chemical characterization of honeys from central Argentina. Food Chemistry, $100,1649-1653$.

[29] Abdulkhaliq, A. and Swaileh, K.M. (2017) Physicochemical properties of multi-floral honey from the West Bank, Palestine. International Journal of Food Properties, 20(2), 447 - 454.

[30] El Sohaimy, S. A., Masry, S. H. D. and Shehata, M. G. 2015. Physicochemical characteristics of honey from different origins. Annals of Agricultural Science, 60, $279-287$.

[31] Andualem, B. 2014. Physico-chemical, microbiological and antibacterial properties of Apis, Mellipodae and Trigona spp. Honey against bacterial pathogens. World Journal of Agricultural Sciences, 10(3), $112-120$.

[32] Venugopal, S. and Devarajan, S. 2010. Estimation of total flavonoids, phenols and antioxidant activity of local Manuka honey. Journal of Pharmacy Research, 4(2), $464-466$.

[33] Zima, T. S., Fialova, L., Mestek, O., Janebova, M., Crkovska, J., Malbohan, I., Stýpek, S., Mikulýkova, L. and Popov, P. 2001. Oxidative stress metabolism of ethanol and alcohol-related diseases. Journal of Biomedical Science, 8, 59-70.

[34] Astley, S.B. 2003. Dietary antioxidants - past, present and future? Trends in Food Science and Technology, 14, $93-98$.

[35] Wang, X.H., Gheldof, N. and Engeseth, N.J., 2004. Effect of processing and storage on antioxidant capacity of honey. Journal of Food Science, 69, 96 $-101$.

[36] Turkmen, N., Sari, F., Poyrazoglu, E.S. and Velioglu, Y.S., 2006. Effects of prolonged heating on antioxidant activity and colour of honey. Food Chemistry, 95(4), $653-657$.

[37] Silva, I. A. A., Silva, T. M. S., Camara, C. A., Queiroz, N., Magnani, M., Novais, J. S., Soledade, L. E. B., Lima, E. O., Souza, A. L and Souza, A. G. 2013. Phenolic profile, antioxidant activity and palynological analysis of stingless bee honey from Amazonas, Northern Brazil. Food Chemistry, 141, $3552-3558$.

[38] Aljadi, A. M. and Kamaruddin, M. Y. 2004. Evaluation of the phenolic contents and antioxidant capacities of two Malaysian floral honeys. Food Chemistry, 85, $513-518$.

[39] Alvarez-Suarez, J. M., Giampieri, F., GonzálezParamás, A. M., Damiani, E., Astolfi, P., MartinezSanchez, G., Bompadre, S., Quiles, J. L., SantosBuelga, C. and Battino, M. 2002. Phenolics from monofloral honeys protect human erythrocyte membranes against oxidative damage. Food and Chemical Toxicology, 50, 1508 - 1516.

[40] Saric, G., Markovic, K., Major, N., Krpan, M., Ursulin-Trstenjak, N., Hruskar, M. and Vahcic, N. 2012. Changes of antioxidant activity and phenolic content in Acacia and multifloral honey during storage. Food Technology and Biotechnology, 50(4), $434-441$.

[41] Habib, H. M., Al Meqbali, F. T., Kamal, H. Souka, U. D. and Ibrahim, W. H. 2014. Physicochemical and biochemical properties of honeys from arid regions. Food Chemistry, 1531, $35-43$.

[42] Kek, S. P., Chin, N. L., Tan, S. W. and Yusof, Y. A. 2016. Classification of honey from its bee origin via chemical profiles and mineral content. Food Analytical Methods, 10, $19-30$.

[43] Ranneh, Y., Ali, F., Zarei, M., Akim, A. M., Hamid, H. A. and Khazaai, H. 2018. Malaysian stingless bee and Tualang honeys: a comparative characterization of total antioxidant capacity and phenolic profile using liquid chromatography-mass spectrometry. LWT- Food Science and Technology, 89, $1-9$. 